\title{
Eddy diffusivities estimated from observations in the Labrador Sea
}

\author{
A. Funk, ${ }^{1}$ P. Brandt, ${ }^{1}$ and T. Fischer ${ }^{1}$ \\ Received 28 August 2008; revised 6 January 2009; accepted 21 January 2009; published 2 April 2009.
}

[1] Eddy diffusivities in the Labrador Sea (LS) are estimated from deep eddy resolving float trajectories, moored current meter records, and satellite altimetry. A mean residence time of 248 days in the central LS is observed with several floats staying for more than 2 years. By applying a simple random walk diffusion model, the observed distribution of float residence times in the central LS could be explained by a mean eddy diffusivity of about $300 \mathrm{~m}^{2} \mathrm{~s}^{-1}$. Estimates from float trajectories themselves and from moored current meter records yield significantly higher eddy diffusivities in the central LS of $950-1100 \mathrm{~m}^{2} \mathrm{~s}^{-1}$. This discrepancy can be explained by an inhomogeneity of the eddy diffusivity at middepth with high/low values in the central LS/region between central LS and deep Labrador Current, which could be conjectured from the mean altimetric eddy kinetic energy (EKE) distribution. The different diffusivities explain both (1) a fast lateral homogenization of water masses in the central LS and (2) a weak exchange between central LS and boundary current. The mean Lagrangian length scale of $11.5 \pm 0.7 \mathrm{~km}$ as estimated from deep float trajectories is only slightly larger than the mean Rossby radius of deformation $(8.8 \mathrm{~km})$. Largest eddy diffusivities within the central LS are associated with strong eddy drifts, rather than with large swirl velocities and associated large EKE.

Citation: Funk, A., P. Brandt, and T. Fischer (2009), Eddy diffusivities estimated from observations in the Labrador Sea, J. Geophys. Res., 114, C04001, doi:10.1029/2008JC005098.

\section{Introduction}

[2] The Labrador Sea (LS), as one of the few sites of open ocean deep convection, has long been a place of intense oceanographic research because of its role in the Atlantic meridional overturning circulation [Talley and McCartney, 1982]. A cyclonic boundary current system around the LS is the main pathway for the overflow waters from the Nordic Seas to the North Atlantic deep western boundary current. The Labrador Sea Water (LSW), as shallowest part of the North Atlantic deep water, is (mainly) formed during intense winterly surface cooling periods in the central LS [Marshall and Schott, 1999]. Its formation shows strong interannual and decadal variability [Lazier et al., 2002; Yashayaev, 2007] and whether other regions of its formation exist is often suggested [Pickart et al., 2003]. LSW is exported out of the LS mainly via the deep Labrador Current [Schott et al., 2004]. While newly formed LSW from the central LS reaches the boundary current predominantly because of isopycnal mixing as conjectured from water mass analyses by Yashayaev et al. [2007], convection near the boundary current was also identified to contribute to the LSW formation [Cuny et al., 2005; Palter et al., 2008].

\footnotetext{
${ }^{1}$ Leibniz-Institut für Meereswissenschaften, IFM-GEOMAR, Kiel, Germany.

Copyright 2009 by the American Geophysical Union. 0148-0227/09/2008JC005098\$09.00
}

[3] Because of small eddy scales of about $10 \mathrm{~km}$, eddy fluxes in the LS cannot be resolved in coarse resolution ocean models but have to be parameterized. The Gent and McWilliams [1990] parametrization is widely used with typical values of $1000 \mathrm{~m}^{2} \mathrm{~s}^{-1}$ for the eddy diffusivity $K_{h}$ [Eden et al., 2007]. Estimates for sensible values of $K_{h}$ are often deduced from large-scale observations of eddy properties or from eddy resolving simulations, but regional variations are often omitted. Following the work of Taylor [1922], the diffusivity is given by $K_{h}=\overline{u^{\prime 2}} T_{\text {int }}$, with $T_{\text {int }}$ being the Lagrangian integral timescale. In practice the timescale is equivalent to a length scale $L_{i n t}=\sqrt{\overline{u^{\prime 2}}} T_{\text {int }}$. Both the eddy diffusivity itself as well as the Lagrangian length scales have been subject to intense analysis from satellite altimetry [Stammer, 1997], float analysis and theoretical considerations [Middleton, 1985; Böning and Cox, 1987; Krauß and Böning, 1987; Böning, 1988; Lumpkin et al., 2002]. However, it is not evident that a functional relation between Eulerian scales as the Rossby radius and the Lagrangian length scale that was derived in a statistical manner from the global ocean, does hold in the Labrador Sea. Eden [2007] suggests that in high latitudes of the North Atlantic an observed length scale from satellite altimetry is proportional to the Rossby radius of deformation.

[4] Observational studies on the restratification of the central LS and the exchange with the boundary current regime have been mostly based on summer CTD sections, altimeter data or float data. The first comprehensive set of float data in the LS consisted of non-eddy-resolving profil- 


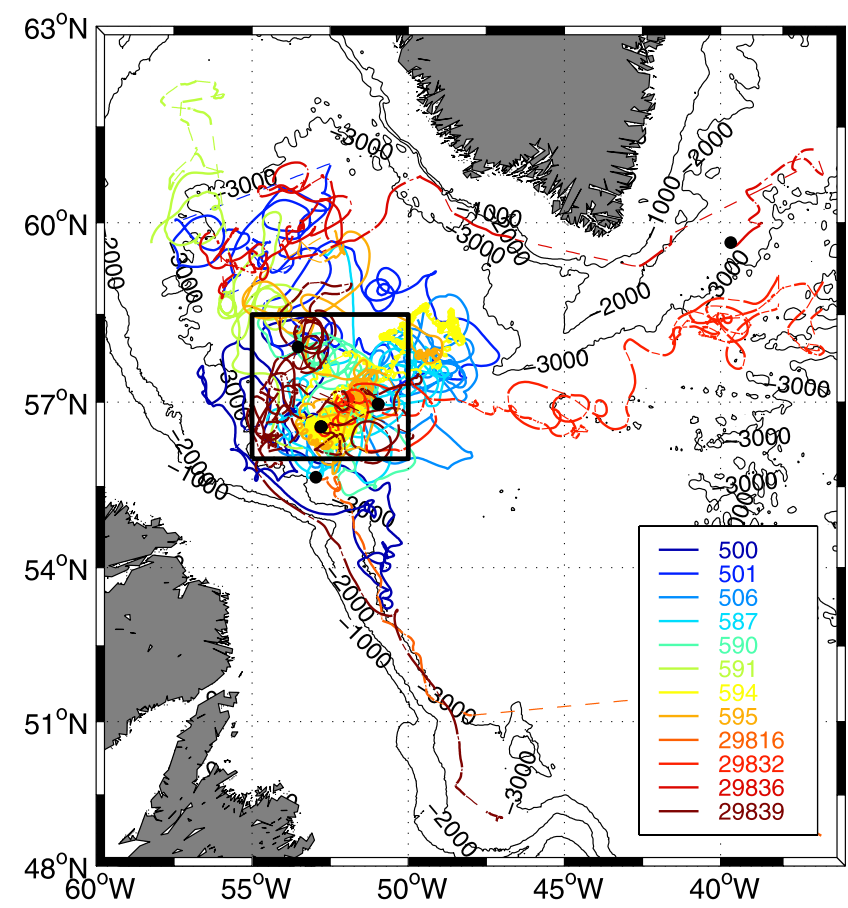

Figure 1. Float trajectories of 12 acoustically tracked floats for the period February 2004 to November 2006. Black box marks central LS region, used in Table 4. Start positions of the floats are marked by black dots.

ing floats [Lavender et al., 2000]. From these floats, Lagrangian integral timescales in the central LS of 4-8 days were estimated using a typical eddy length scale of $20 \mathrm{~km}$ and observed RMS velocities of $3-6 \mathrm{~cm} \mathrm{~s}^{-1}$ [Straneo et al., 2003]. The small time and length scales suggest that highresolution trajectories might be necessary to analyze eddy mixing. However, up to now only a few eddy resolving float trajectories from acoustically tracked floats are available [Prater, 2002]. Using the above mentioned $20 \mathrm{~km}$ length scale and $u^{\prime}$ from float trajectories Straneo et al. [2003] estimated eddy diffusivities between 200 and $1200 \mathrm{~m}^{2} \mathrm{~s}^{-1}$ in the LS, while Kvaleberg et al. [2008] found by analyzing chlorofluorocarbon (CFC) concentrations in an advective- diffusive model using a float derived velocity field, that horizontal eddy diffusivities between 500 and $3000 \mathrm{~m}^{2} \mathrm{~s}^{-1}$ gave most realistic CFC distributions, however they complained about the still unsatisfying results. Khatiwala et al. [2002] estimated the eddy diffusivity to be $300-600 \mathrm{~m}^{2} \mathrm{~s}^{-1}$ on the basis of an analysis of the annual cycle of potential density during 1964-1974 in the central LS.

[5] In this study we analyze eddy resolving float trajectories including 1500 eddy days acquired in the central LS during 2004-2006 and derive estimates of eddy diffusivities. These are compared with independent estimates from moored current meter records, altimetry, and estimates from a larger non-eddy-resolving float data set including Argo float trajectories. In the second section we will describe the float experiment and the other data used. A detailed description of several independent methods used to estimate the eddy diffusivity is given in section 3 . In section 4, we discuss in detail an example of an eddying float trajectory and corresponding eddy scales and diffusivities and we present eddy diffusivity estimates obtained from different data sets. Finally, a summarizing discussion is given.

\section{Data}

\subsection{Float Experiment}

[6] During 2003 and 2004 a total amount of 22 acoustically tracked floats were deployed to track eddy activity in the central LS (Figure 1). In September 2003 a set of 9 Seascan RAFOS floats was parked at 3 locations in the central LS using the dual release technique [Zenk et al., 2000] to start their mission at the end of the convective season in late winter/early spring 2004. A second set of 9 Seascan floats was deployed in September 2004 to start their mission at the end of the convective season 2005 . Unfortunately we got data from only 8 of these 18 floats. Furthermore a set of 4 acoustically tracked profiling Webb Autonomous Profiling Explorer floats was deployed in September 2004 and started their mission immediately (Table 1). These floats were profiling and surfacing once a week, so that their surface positions were known. Acoustical tracking of the floats was done using 4 sound sources, two of them that pinged 3 times per day were deployed during Meteor cruise M59/3 in September 2003 and redeployed with fresh batteries in August 2005 during a cruise

Table 1. Start and End Positions of Acoustically Tracked Float Trajectories ${ }^{\mathrm{a}}$

\begin{tabular}{|c|c|c|c|c|c|c|c|c|}
\hline \multirow[b]{2}{*}{ Identifier } & \multirow[b]{2}{*}{ Depth (m) } & \multirow[b]{2}{*}{ Type } & \multicolumn{3}{|c|}{ Start of Trajectory } & \multicolumn{3}{|c|}{ End of Trajectory } \\
\hline & & & Date & Latitude & Longitude & Date & Latitude & Longitude \\
\hline 500 & 925 & RAFOS & 29 Feb 2004 & $56^{\circ} 34^{\prime} \mathrm{N}$ & $52^{\circ} 48^{\prime} \mathrm{W}$ & 30 Jun 2005 & $57^{\circ} 30^{\prime} \mathrm{N}$ & $52^{\circ} 41^{\prime} \mathrm{W}$ \\
\hline 501 & 940 & RAFOS & 29 Feb 2004 & $57^{\circ} 57^{\prime} \mathrm{N}$ & $53^{\circ} 32^{\prime} \mathrm{W}$ & 30 Jun 2005 & $59^{\circ} 52^{\prime} \mathrm{N}$ & $55^{\circ} 49^{\prime} \mathrm{W}$ \\
\hline 506 & 925 & RAFOS & 30 Mar 2004 & $56^{\circ} 34^{\prime} \mathrm{N}$ & $52^{\circ} 48^{\prime} \mathrm{W}$ & 30 Jul 2005 & $58^{\circ} 38^{\prime} \mathrm{N}$ & $50^{\circ} 01^{\prime} \mathrm{W}$ \\
\hline 587 & 965 & RAFOS & $28 \mathrm{Feb} 2005$ & $56^{\circ} 58^{\prime} \mathrm{N}$ & $50^{\circ} 58^{\prime} \mathrm{W}$ & 30 Jun 2006 & $59^{\circ} 31^{\prime} \mathrm{N}$ & $52^{\circ} 29^{\prime} \mathrm{W}$ \\
\hline 590 & 980 & RAFOS & 15 Mar 2005 & $56^{\circ} 58^{\prime} \mathrm{N}$ & $50^{\circ} 58^{\prime} \mathrm{W}$ & 15 Jul 2006 & $57^{\circ} 58^{\prime} \mathrm{N}$ & $53^{\circ} 11^{\prime} \mathrm{W}$ \\
\hline 591 & 945 & RAFOS & 15 Mar 2005 & $56^{\circ} 34^{\prime} \mathrm{N}$ & $52^{\circ} 47^{\prime} \mathrm{W}$ & 15 Jul 2006 & $59^{\circ} 31^{\prime} \mathrm{N}$ & $57^{\circ} 59^{\prime} \mathrm{W}$ \\
\hline 594 & 835 & RAFOS & 30 Mar 2005 & $56^{\circ} 34^{\prime} \mathrm{N}$ & $52^{\circ} 48^{\prime} \mathrm{W}$ & 30 Jul 2006 & $56^{\circ} 45^{\prime} \mathrm{N}$ & $52^{\circ} 25^{\prime} \mathrm{W}$ \\
\hline 595 & 1090 & RAFOS & 30 Mar 2005 & $56^{\circ} 58^{\prime} \mathrm{N}$ & $50^{\circ} 58^{\prime} \mathrm{W}$ & 30 Jul 2006 & $57^{\circ} 54^{\prime} \mathrm{N}$ & $50^{\circ} 05^{\prime} \mathrm{W}$ \\
\hline 29816 & 800 & APEX & 2 Sep 2004 & $55^{\circ} 40^{\prime} \mathrm{N}$ & $52^{\circ} 58^{\prime} \mathrm{W}$ & 4 Jan 2007 & $44^{\circ} 57^{\prime} \mathrm{N}$ & $22^{\circ} 13^{\prime} \mathrm{W}$ \\
\hline 29832 & 800 & APEX & 1 Sep 2004 & $56^{\circ} 34^{\prime} \mathrm{N}$ & $52^{\circ} 48^{\prime} \mathrm{W}$ & 31 May 2006 & $59^{\circ} 23^{\prime} \mathrm{N}$ & $35^{\circ} 02^{\prime} \mathrm{W}$ \\
\hline 29836 & 800 & APEX & 19 Sep 2004 & $59^{\circ} 41^{\prime} \mathrm{N}$ & $50^{\circ} 58^{\prime} \mathrm{W}$ & 21 May 2006 & $57^{\circ} 58^{\prime} \mathrm{N}$ & $58^{\circ} 13^{\prime} \mathrm{W}$ \\
\hline 29839 & 800 & APEX & 15 Sep 2004 & $56^{\circ} 58^{\prime} \mathrm{N}$ & $39^{\circ} 40^{\prime} \mathrm{W}$ & 22 Nov 2006 & $48^{\circ} 51^{\prime} \mathrm{N}$ & $46^{\circ} 58^{\prime} \mathrm{W}$ \\
\hline
\end{tabular}

${ }^{\mathrm{a} A P E X}$, Autonomous Profiling Explorer. 
Table 2. Sound Sources

\begin{tabular}{ccccccc}
\hline Sound Source & Deployment & Recovery & Latitude & Longitude & Depth (m) & UTC Time of Signal \\
\hline 15 & 6 Sep 2003 & 19 Jul 2005 & $53^{\circ} 07.89^{\prime} \mathrm{N}$ & $50^{\circ} 51.57^{\prime} \mathrm{W}$ & 1037 & $0230,1030,1830$ \\
20 & 10 Sep 2003 & 21 Jul 2005 & $57^{\circ} 04.81^{\prime} \mathrm{N}$ & $52^{\circ} 06.04^{\prime} \mathrm{W}$ & 960 & $0200,1000,1800$ \\
15 & 22 Jul 2005 & 7 Jun 2007 & $56^{\circ} 31.50^{\prime} \mathrm{N}$ & $52^{\circ} 39.00^{\prime} \mathrm{W}$ & 1013 & $0230,1030,1830$ \\
20 & 25 Jul 2005 & 31 May 2007 & $53^{\circ} 08.00^{\prime} \mathrm{N}$ & $50^{\circ} 52.10^{\prime} \mathrm{W}$ & 931 & $0200,1000,1800$ \\
$\mathrm{E}^{\mathrm{a}}$ & 6 Aug 2005 & & $43^{\circ} 30.25^{\prime} \mathrm{N}$ & $40^{\circ} 00.52^{\prime} \mathrm{W}$ & 1203 & 0230 \\
$\mathrm{C}^{\mathrm{a}}$ & 8 Aug 2005 & & $45^{\circ} 00.00^{\prime} \mathrm{N}$ & $35^{\circ} 58.17^{\prime} \mathrm{W}$ & 1173 & 0130 \\
\hline
\end{tabular}

${ }^{a}$ From Woods Hole Oceanographic Institution.

on $\mathrm{R} / \mathrm{V}$ Thalassa (Table 2). The other two sound sources that pinged once a day were part of the Woods Hole Oceanographic Institution export pathways project (http:// www.whoi.edu/science/po/people/abower/EXPATHmain.html). The float tracking was done using the ARTOA software package [Wooding et al., 2005]. To get smooth trajectories without artificial noise due to bad acoustics, a low-pass filter with a Hamming window and a cutoff period of 2 days has been applied to the trajectories, except for one float (594) from which we got high-quality acoustic data and found an eddy period of significantly less than 2 days. This trajectory has been smoothed with a low-pass filter having a 1 day cutoff period.

\subsection{Moored Data}

[7] The central LS mooring K1 located at $56^{\circ} 33^{\prime} \mathrm{N}$, $52^{\circ} 40^{\prime} \mathrm{W}$ (Figure 2a) has been maintained since 1996 with yearly redeployments [Avsic et al., 2006]. Its main purpose was the observation of hydrographic properties including mixed layer depth but it also contained Acoustic Doppler Current Profilers (ADCP) and some Aanderaa or FSI current meters distributed over the whole water column.
Some current meter mooring data from single years northwest of K1 just offshore of the deep Labrador Current have been additionally used (Figure 2a).

\subsection{Altimeter Data}

[8] Eddy kinetic energy (EKE) was calculated from the sea level anomaly (SLA) gradients of the along-track data of the single satellites provided by AVISO for the period 1992 to 2006. The across-track geostrophic velocities $v_{c}$ were calculated from the along track-gradients $\frac{\partial \eta}{\partial s}$ of the low-pass filtered SLA data by $v_{c}=\frac{g}{f} \frac{\partial \eta}{\partial s}$, with the gravitational constant $g$ and the Coriolis parameter $f$. Under the assumption of isotropic velocity variance the EKE is derived as

$$
E K E=\overline{\frac{1}{2}\left(v_{c}^{2}+v_{a}^{2}\right)}=\overline{v_{c}^{2}}
$$

where $v_{a}$ is the unknown along-track velocity. Processing was similar to Brandt et al. [2004] except for the following differences: Instead of corrections with regard to the significant wave height, a filter with a longer (five-point or approximately $32 \mathrm{~km}$ instead of three-point) Hamming
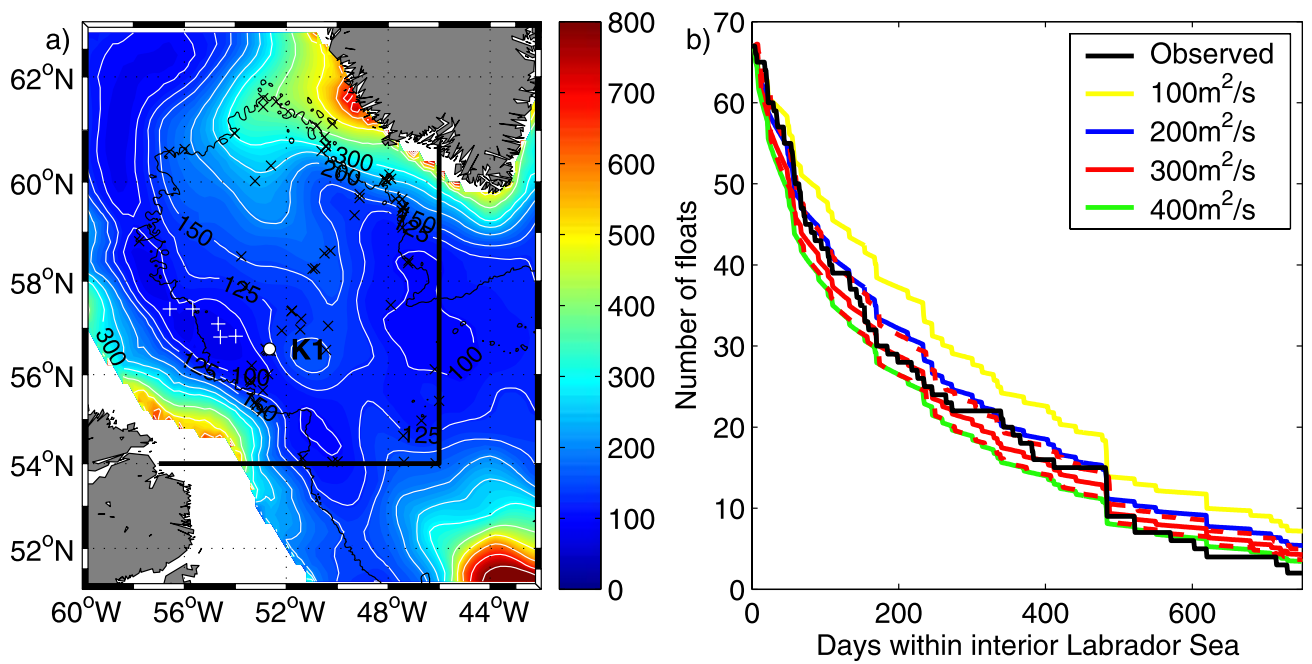

Figure 2. (a) EKE in $\mathrm{cm}^{2} \mathrm{~s}^{-2}$ from altimetry during 1992 to 2006 (colored map and white contour lines). The thin black line denotes the $3000 \mathrm{~m}$ isobath. Black times signs mark starting positions of the floats, the white point marks the position of the central LS mooring K1, and white plus signs mark positions of other current meter moorings. The thick black line along $54^{\circ} \mathrm{N}$ and $46^{\circ} \mathrm{W}$ marks southern and eastern boundary of the central LS region used for determination of residence times. (b) Residence time distribution of floats in the central LS. Black line denotes distribution from observed float trajectories, and colored lines denote distributions from a random walk model with the given eddy diffusivities. The dashed red lines mark a difference of one standard deviation around the $300 \mathrm{~m}^{2} \mathrm{~s}^{-1}$ line from repeat random walk simulations. 
Table 3. Scale Factor and Offset for EKE From Different Satellites Determined From the Area Between $40^{\circ} \mathrm{N}$ and $58^{\circ} \mathrm{N}$ and $62^{\circ} \mathrm{W}$ and $48^{\circ} \mathrm{W}$ for the Overlapping Period With Topex/ Poseidon $^{\mathrm{a}}$

\begin{tabular}{lccc}
\hline \multicolumn{1}{c}{ Satellite } & Overlapping Period & $\begin{array}{c}\text { Scale } \\
\text { Factor } a\end{array}$ & $\begin{array}{c}\text { Offset } b \\
\left(\mathrm{~cm}^{2} \mathrm{~s}^{-2}\right)\end{array}$ \\
\hline TOPEX/Poseidon & Oct 1992 to Oct 2005 & 1 & 0 \\
ERS-2 & May 1995 to Jun 2003 & 0.93 & -129 \\
GFO & Jan 2000 to Oct 2005 & 0.91 & -64 \\
Jason-1 & Jan 2002 to Oct 2005 & 0.90 & -74 \\
Envisat & Nov 2002 to Oct 2005 & 0.90 & 24 \\
\hline
\end{tabular}

${ }^{\mathrm{a}}$ Corrected EKE $E_{c}$ results from $E_{c}=a \times E K E+b$.

window was applied to the along-track data. A comparison of the resulting EKE products for the different satellites showed differences in means and standard deviations of the calculated EKE, possibly because of different noise levels inherent in the altimeter measurements. To correct for these differences, all single satellite EKE data of the region between $40^{\circ} \mathrm{N}$ and $58^{\circ} \mathrm{N}$ and $62^{\circ} \mathrm{W}$ and $48^{\circ} \mathrm{W}$ have been adjusted to the Topex/Poseidon EKE data by applying a temporal and spatial mean offset and scaling factor to the along-track data that yielded the same mean and standard deviation of EKE for overlapping periods of the different satellite missions (Table 3).

\subsection{Argo Floats}

[9] To increase the database we also used trajectories of Argo floats from the years 2001 to 2007, even though these are not eddy resolving. These trajectories are typically given with a resolution of 10 days (the surfacing intervals) which is sufficient to estimate whether or not a float has left the central LS and has found its way into the boundary current system. Those floats were drifting at depths between 900 and $2000 \mathrm{~m}$, most of them at $1500 \mathrm{~m}$. The combined Argo and RAFOS data set includes 16,636 float days in the central LS with a total lifetime of 29,964 days.

\section{Methods to Calculate Eddy Diffusivities}

[10] One estimate of the eddy diffusivity was calculated from the combined data set of our acoustically tracked floats and the Argo float data set. For this estimation all float trajectories that started within or passed by a region north of $54^{\circ} \mathrm{N}$ and west of $46^{\circ} \mathrm{W}$ (Figure 2a) comprising water depths larger than $3000 \mathrm{~m}$ were evaluated. In total 67 trajectories have been found that start within the central region. The residence time distribution of these floats in the central region is shown in Figure $2 b$.

[11] To obtain an estimate of the eddy diffusivity $K_{h}$ the residence time distribution has been compared to theoretical curves calculated from a random walk model. In the random walk model that simulates a purely diffusive process one considers the two-dimensional probability distribution $p(\mathbf{r})$ of a diffusive tracer expansion:

$$
p(\mathbf{r})=\frac{1}{2 \pi \sigma_{r}^{2}} \exp \left(\frac{-r^{2}}{2 \sigma_{r}^{2}}\right)
$$

with $\mathbf{r}=(x, y), r=\sqrt{x^{2}+y^{2}}$, and the characteristic width $\sigma_{r}$. The second moment is

$$
\left\langle r^{2}\right\rangle=\int_{0}^{2 \pi} \int_{0}^{\infty} r^{2} p(\mathbf{r}) r d r d \phi=2 \sigma_{r}^{2} .
$$

[12] We used a random walk model generated by a random uniformly distributed direction and a random uniformly distributed step size between 0 and a maximum step size $R_{m}$. This can be described by the probability distribution

$$
p(\mathbf{r})=\frac{1}{2 \pi r R_{m}} .
$$

Its second moment for a single step is

$$
\left\langle r^{2}\right\rangle=R_{m}^{2} / 3,
$$

for $N$ steps it will be $N R_{m}^{2} / 3$. From the diffusion equation we obtain $\sigma_{r}^{2}=2 K_{h} t=2 K_{h} N \Delta t$, for the case of $N$ time steps $\Delta t$. Combining the second moments of the random walk model and the diffusion equation yields

$$
4 K_{h} N \Delta t=2 \sigma_{r}^{2}=N R_{m}^{2} / 3
$$

or $R_{m}=\sqrt{12 K_{h} \Delta t}$. This allows us to simulate a diffusive process with a given diffusivity by random walk trajectories. We can compare the residence time distribution of the simulated trajectories for a given diffusivity with the observed residence time distribution and search for the closest match. It is important to note however, that the residence times depend on the start positions of the floats. In our case a large number of in situ floats start their trajectories very close to the boundary and have a high probability of leaving the region very fast. The simulations have been repeated 1000 times starting at the 67 initial positions of the in situ floats and mean distributions and their respective standard deviations were calculated (Figure $2 \mathrm{~b}$ ). A second run of the random walk model with randomly distributed start positions generated larger residence times as the initial mean distance to the boundary was larger. The random walk calculations were performed using a time step of 1 day. This time step is small enough to avoid an influence of its choice on the obtained residence times. The time mean velocity in the central LS calculated from float trajectories that could affect the residence time calculations is close to zero and in general below its standard error.

[13] From an earlier experiment [Fischer and Schott, 2002] the question arose whether the surface drift of the profiling Argo floats influences the total trajectory of these floats. Fischer and Schott [2002] found that the surface drifts of profiling floats at the exit of the LS may reach up to $25 \%$ of the total drift. However, they also described that the direction of the surface drift was almost (within $20^{\circ}$ ) the same as the subsurface drift at $1500 \mathrm{~m}$ depth. For our acoustically tracked profiling floats, we kept the surface time to the minimum possible value which is a total of 12 hours including the descent from park level to $2000 \mathrm{~m}$, the subsequent ascent to surface and data transmission time at surface. This results in maximum data transmission times at surface of 8 hours. A study near the mid-Atlantic ridge 
Table 4. Lagrangian Scales, Diffusivities, and EKE in the Central LS $^{\mathrm{a}}$

\begin{tabular}{|c|c|c|c|c|c|c|}
\hline & Value & Mean & $\begin{array}{c}\text { January, February, } \\
\text { and March }\end{array}$ & $\begin{array}{l}\text { April, May, } \\
\text { and June }\end{array}$ & $\begin{array}{l}\text { July, August, } \\
\text { and September }\end{array}$ & $\begin{array}{c}\text { October, November, } \\
\text { and December }\end{array}$ \\
\hline \multirow[t]{4}{*}{ Float trajectories } & $T_{\text {int }}$ (days) & $2.46 \pm 0.27$ & $3.12 \pm 0.66$ & $1.30 \pm 0.28$ & $3.52 \pm 0.77$ & $1.87 \pm 0.44$ \\
\hline & $L_{\text {int }}(\mathrm{km})$ & $11.5 \pm 0.7$ & $13.9 \pm 1.5$ & $10.9 \pm 1.7$ & $11.1 \pm 1.0$ & $10.0 \pm 1.2$ \\
\hline & EKE $\left(\mathrm{cm}^{2} \mathrm{~s}^{-2}\right)$ & $100 \pm 17$ & $101 \pm 40$ & $112 \pm 36$ & $99 \pm 34$ & $87 \pm 23$ \\
\hline & $K_{h}\left(\mathrm{~m}^{2} \mathrm{~s}^{-1}\right)$ & $948 \pm 101$ & $997 \pm 250$ & $1187 \pm 215$ & $847 \pm 170$ & $761 \pm 174$ \\
\hline \multirow{2}{*}{ Altimetry } & $\operatorname{EKE}\left(\mathrm{cm}^{2} \mathrm{~s}^{-2}\right)$ & $127 \pm 7$ & $126 \pm 12$ & $168 \pm 15$ & $147 \pm 22$ & $67 \pm 11$ \\
\hline & $K_{h}\left(\mathrm{~m}^{2} \mathrm{~s}^{-1}\right)$ & 989 & 954 & 1160 & 1073 & 721 \\
\hline Argo & Rossby radius $(\mathrm{km})$ & $8.78 \pm 0.02$ & $8.50 \pm 0.06$ & $8.95 \pm 0.05$ & $8.85 \pm 0.04$ & $8.81 \pm 0.04$ \\
\hline \multicolumn{7}{|c|}{ Moored current meters } \\
\hline Near-surface & $\begin{array}{c}\operatorname{EKE}\left(\mathrm{cm}^{2} \mathrm{~s}^{-2}\right) \\
K_{h}\left(\mathrm{~m}^{2} \mathrm{~s}^{-1}\right)\end{array}$ & $\begin{array}{c}148 \pm 24 \\
1068\end{array}$ & $\begin{array}{c}124 \pm 35 \\
947\end{array}$ & $\begin{array}{c}243 \pm 66 \\
1395\end{array}$ & $\begin{array}{c}145 \pm 51 \\
1066\end{array}$ & $\begin{array}{c}81 \pm 39 \\
793\end{array}$ \\
\hline$<1000 \mathrm{~m}$ & $\begin{array}{c}\mathrm{EKE}\left(\mathrm{cm}^{2} \mathrm{~s}^{-2}\right) \\
K_{h}\left(\mathrm{~m}^{2} \mathrm{~s}^{-1}\right)\end{array}$ & $\begin{array}{c}153 \pm 19 \\
1086\end{array}$ & $\begin{array}{c}132 \pm 19 \\
977\end{array}$ & $\begin{array}{c}249 \pm 136 \\
1412\end{array}$ & $\begin{array}{c}135 \pm 21 \\
1028\end{array}$ & $\begin{array}{c}94 \pm 22 \\
854\end{array}$ \\
\hline $1000-2000 \mathrm{~m}$ & $\begin{array}{c}\mathrm{EKE}\left(\mathrm{cm}^{2} \mathrm{~s}^{-2}\right) \\
K_{h}\left(\mathrm{~m}^{2} \mathrm{~s}^{-1}\right)\end{array}$ & $\begin{array}{c}118 \pm 38 \\
954\end{array}$ & $\begin{array}{c}109 \pm 44 \\
887\end{array}$ & $\begin{array}{c}201 \pm 68 \\
1269\end{array}$ & $\begin{array}{c}94 \pm 42 \\
858\end{array}$ & $\begin{array}{c}70 \pm 44 \\
737\end{array}$ \\
\hline$>2000 \mathrm{~m}$ & $\begin{array}{c}\mathrm{EKE}\left(\mathrm{cm}^{2} \mathrm{~s}^{-2}\right) \\
K_{h}\left(\mathrm{~m}^{2} \mathrm{~s}^{-1}\right)\end{array}$ & $\begin{array}{c}64 \pm 32 \\
702\end{array}$ & $\begin{array}{c}58 \pm 24 \\
647\end{array}$ & $\begin{array}{c}86 \pm 52 \\
830\end{array}$ & $\begin{array}{c}54 \pm 22 \\
650\end{array}$ & $\begin{array}{c}53 \pm 32 \\
641\end{array}$ \\
\hline
\end{tabular}

${ }^{a}$ Float trajectories altimetry and Argo data correspond to the box shown in Figure 1. Moored current meter data is acquired at mooring K1 (see Figure 2a).

[Machín et al., 2006] directly compared velocity estimates from profiling floats and nonprofiling floats and found them to be comparable. Even knowing the surface drift, there is no means to subtract its effect on the residence time approach. To exclude an effect of the 10 day sampling we will present also results from a random walk calculation using a 1 day time step as in the normal run but tested for the residence time every 10 days only.

[14] A bias in the residence time distribution might result as the simulated floats in principle have unlimited life times, while the observed floats only have a limited time before their programmed missions end or their batteries run low. In this case they still might stay in the central region at the end of their life time. To compensate for this bias the residence time distributions of the simulated trajectories have been adjusted in such a way, that they have the same distribution of total life time as the observed floats. This has been achieved by multiplying the simulated distributions with the lifetime factor $f(\tau)=n(\tau) / n(0)$, with $n(\tau)$ being the number of floats that still exist after time $\tau$.

[15] A method for calculating the eddy diffusivity directly from the float trajectories was described, e.g., by Lumpkin et $a l$. [2002]. The eddy diffusivity can be deduced from the float trajectories by directly calculating the Lagrangian integral timescale

$$
T_{\text {int }}=\int_{0}^{\infty} R(\tau) d \tau
$$

with $R(\tau)$ the autocorrelation function of the float's velocity $u$. The integral had not been evaluated to infinity but to an upper limit of 40 days. The eddy diffusivity is given by

$$
K_{h}=\overline{u^{\prime 2}} T_{i n t}
$$

From the Lagrangian timescale a Lagrangian length scale was determined by $L_{i n t}=\sqrt{\overline{u^{\prime 2}}} T_{i n t}$ [see, e.g., Böning and Cox, 1987].

[16] All above mentioned quantities were calculated separately for each 8 hour time step of each float with the averages being calculated over the time period from 20 days before to 20 days after the actual time step. All primed quantities denote the deviation from these 40 day running means. The 40 day timescale was chosen large enough to induce no artificial upper bound for $T_{i n t}$ and short enough to avoid false detection of seasonal variability as eddy diffusive processes.

[17] A totally independent estimate is also available by analyzing time series of moored current profilers. For this we analyzed all current meter records of the long-term time series mooring in the central LS. For all instruments the EKE for the whole deployment period of typically 1 year has been calculated and the diffusivity has been derived by $K_{h}=\sqrt{\overline{u^{\prime 2}}} L_{\text {int }}$. Typically one ADCP and one to three FSI-ACMs or Aanderaa RCMs were deployed within the central LS mooring. Data sets acquired during each deployment period from each instrument have been treated as independent records, from each ADCP data set typically covering a depth range of about $300 \mathrm{~m}$ 4 uniformly distributed depth bins have been treated as independent records. The Lagrangian length scale $L_{\text {int }}$ cannot be determined by the current meter records, instead the first baroclinic Rossby radius as calculated from Argo float profiles from the LS box (Figure 1) and World Ocean Atlas 2005 climatology [Locarnini et al., 2006; Antonov et al., 2006] for depths deeper than $2000 \mathrm{~m}$ have been used. However, Lagrangian scales obtained from the acoustically tracked floats (see Table 4) and the Rossby radius are of the same order of magnitude. Similarly to the calculation of eddy diffusivities from moored EKE data, eddy diffusivities from altimetric EKE data were obtained using the same baroclinic Rossby radius.

\section{Results}

[18] For a very eddying trajectory (Figure 3 ) the Lagrangian scales and the deduced eddy diffusivities are shown in Figure 4. Starting from near the mooring position $\mathrm{K} 1$ in April 2004 this float moved in an anticyclonic way to the northeast and turned back to its starting position with almost constant eddy period (1.6 days) and radius. After some days in February/March 2006 when we could not track the float 


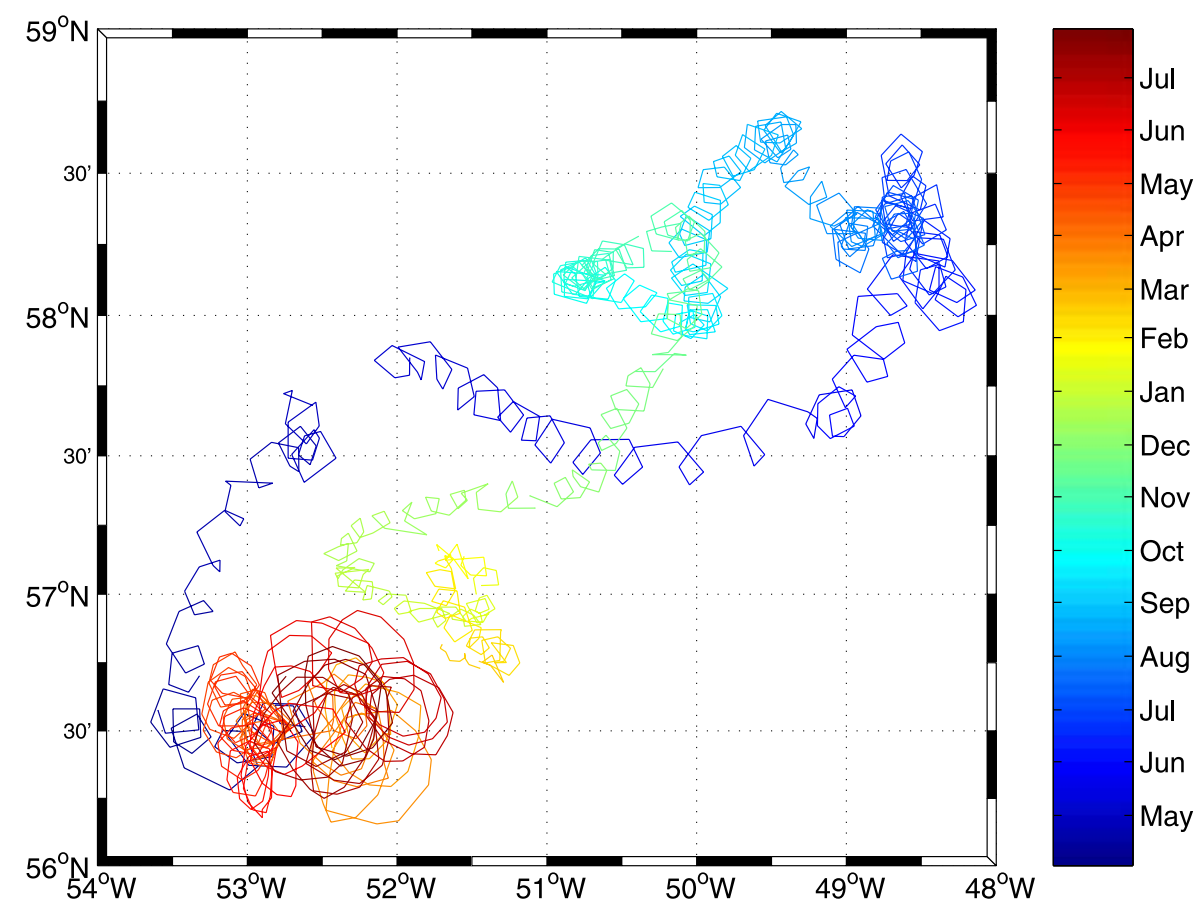

Figure 3. Trajectory of float 594 (April 2005 to July 2006).

because of bad acoustic conditions associated with the winter sound velocity profile, larger periods (2.3 days) and radii were observed. It was also found, that the temperature dropped by about $0.4^{\circ} \mathrm{C}$ in this period. The swirl velocities also changed and varied roughly between -20 and $+20 \mathrm{~cm} \mathrm{~s}^{-1}$ for the first period and between -30 and $+30 \mathrm{~cm} \mathrm{~s}^{-1}$ for the second period.

[19] However, in this example the Lagrangian timescale is not correlated with the eddy swirl velocity but more with the background velocities. These show periods of mean eddy drifts in an almost constant direction in May and December 2005 leading to Lagrangian scales of up to 4 days in longitude and 3 days in latitude, while for the pure vortex motion scales of the order of $1 / 3$ of a day were found (which is also the time resolution of our sound sources). The corresponding Lagrangian length scales are in the range of 5 to $50 \mathrm{~km}$. The resulting eddy diffusivities show large variations between values below $500 \mathrm{~m}^{2} \mathrm{~s}^{-1}$ and above $5000 \mathrm{~m}^{2} \mathrm{~s}^{-1}$ with the maxima not associated with periods of largest EKE but with largest Lagrangian timescales. From the total acoustically tracked float data set a mean Lagrangian timescale of $2.5 \pm 0.3$ days was found in a box in the central LS (see Figure 1), the mean Lagrangian length scale was $11.5 \pm 0.7 \mathrm{~km}$, the EKE $100 \pm 17 \mathrm{~cm}^{2} \mathrm{~s}^{-2}$ and the eddy diffusivity was $948 \pm 101 \mathrm{~m}^{2} \mathrm{~s}^{-1}$ (see Table 4).

[20] Half of the trajectories from the combined Argo/ RAFOS data set have a residence time in the LS above 153 days (Figure 2b), the mean residence time is 248 days. As discussed before some floats stayed in the central LS at the end of their mission, so that the true mean residence time is even higher. Eight floats (501, 506, 587, 590, 591, 594, 595, 29836, see Table 1) of the 10 acoustically tracked floats that started their mission in the central LS (29832, 29836 and the 8 nonprofiling RAFOS floats) were still in the central LS region after 16 months, one float (500) left the central LS within the western boundary current but returned within the recirculation cell. The numerical experiment with the random walk diffusion model shows that a spatially homogeneous eddy diffusivity of about $300 \mathrm{~m}^{2} \mathrm{~s}^{-1}$ is required to get the closest match between simulated and observed residence time distribution (Figure 2b). A test calculation with a 10 day sampling of the random walk model shows only a slight effect of the different sampling that leads to an eddy diffusivity of $350-400 \mathrm{~m}^{2} \mathrm{~s}^{-1}$ needed to get the same residence time distribution as for the $300 \mathrm{~m}^{2} \mathrm{~s}^{-1}$ case with 1 day sampling (Figure 5). Observed float residence times calculated only from acoustically tracked floats excluding the profiling floats are the same compared to calculations using the full float data set. These residence times match best with an eddy diffusivity of about $300 \mathrm{~m}^{2} \mathrm{~s}^{-1}$, however the standard deviation for this limited data set increases by more than a factor of two compared to the full data set (see Figure $2 b$ ).

[21] For the central LS region eddy diffusivities can be obtained by different measures. From altimetric geostrophic surface currents we obtained a mean EKE of $127 \mathrm{~cm}^{2} \mathrm{~s}^{-2}$. The baroclinic Rossby radius in this region is $8.8 \mathrm{~km}$ yielding an eddy diffusivity of $989 \mathrm{~m}^{2} \mathrm{~s}^{-1}$. This estimate is in good agreement with near surface EKE estimates from the moored current meter records at mooring K1. For the near surface (around $250 \mathrm{~m}$ depth) EKE we found a mean value of $148 \mathrm{~cm}^{2} \mathrm{~s}^{-2}$. This value decreases to $118 \mathrm{~cm}^{2} \mathrm{~s}^{-2}$ at a depth of $1500 \mathrm{~m}$ and $64 \mathrm{~cm}^{2} \mathrm{~s}^{-2}$ at a depth of $3000 \mathrm{~m}$ (Figure 6 and Table 4).

[22] As can also be seen in the map of altimetric EKE (Figure 2a) between the two regions of relatively high EKE in the central LS around mooring $\mathrm{K} 1$ and a region of intensified EKE near the Labrador Current a low-EKE region exists. From different 1 year moorings (white plus 

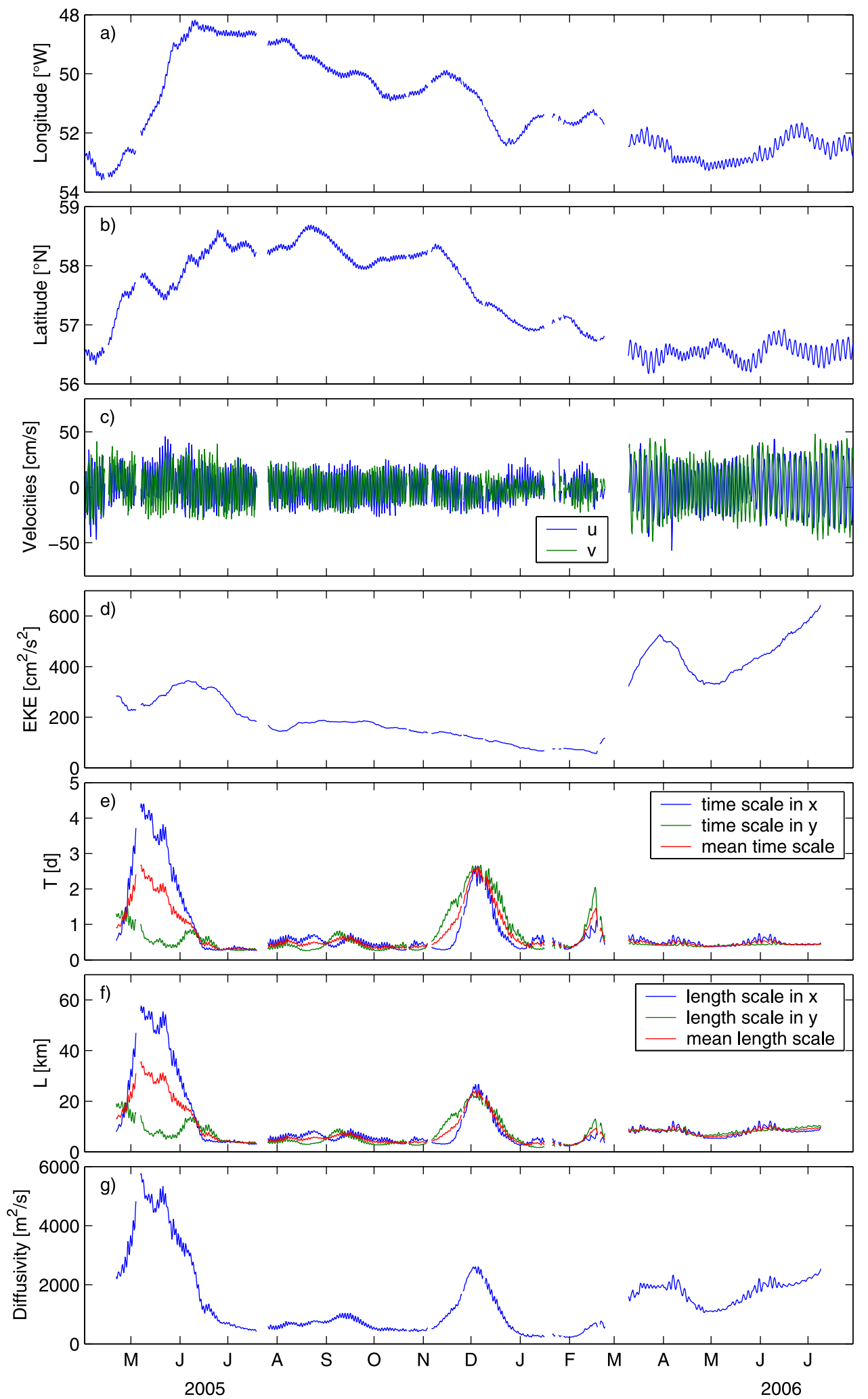

Figure 4. (a) Longitude; (b) latitude; (c) zonal and meridional velocities; (d) EKE; (e) zonal, meridional, and mean Lagrangian timescales; (f) zonal, meridional, and mean Lagrangian length scales; and (g) eddy diffusivity from trajectory of RAFOS float 594 (see Figure 3).

signs, Figure 2a) in the region we found that this pattern is a depth-independent effect. For the low-EKE region and depths shallower than $1000 \mathrm{~m}$ we found an EKE of
$68 \mathrm{~cm}^{2} \mathrm{~s}^{-2}$. For the deeper layers only 3 records exists, at $1328 \mathrm{~m}$ with $29 \mathrm{~cm}^{2} \mathrm{~s}^{-2}, 3023 \mathrm{~m}$ with $11 \mathrm{~cm}^{2} \mathrm{~s}^{-2}$, and $3121 \mathrm{~m}$ with $38 \mathrm{~cm}^{2} \mathrm{~s}^{-2}$ (see Figure 6). 


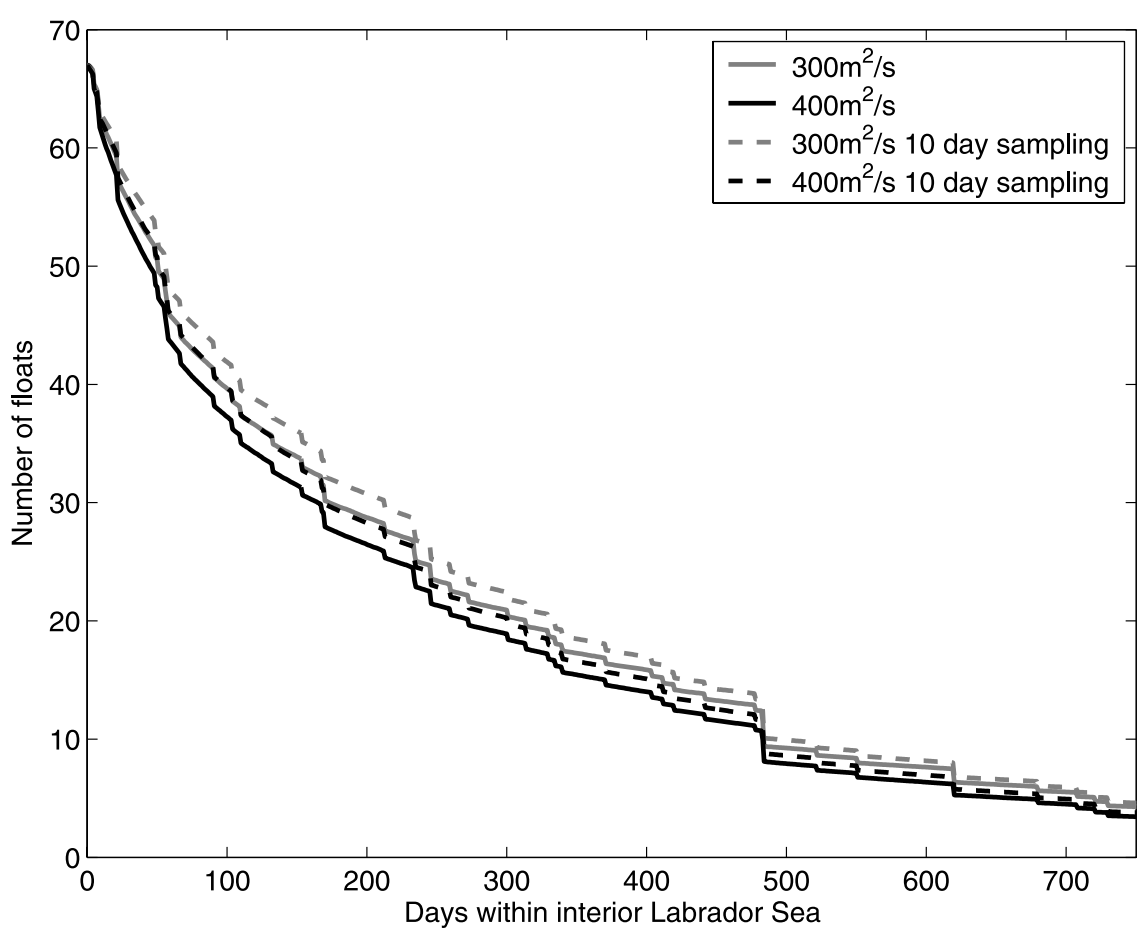

Figure 5. Residence time distribution from random walk model with 1 day time step (solid lines) and 1 day time step with 10 day sampling (dashed lines) for an eddy diffusivity of $300 \mathrm{~m}^{2} \mathrm{~s}^{-1}$ (gray lines) and for $400 \mathrm{~m}^{2} \mathrm{~s}^{-1}$ (black lines).

[23] A regional distribution of Lagrangian length and timescales derived from float trajectories (Figure 7) shows typical values for the central LS between 7 and $40 \mathrm{~km}$ and 1.5 and 8 days. The boundary current regime is characterized by substantially larger scales, that are however deduced from a small amount of float days with correspondingly high statistical errors.

[24] An important assumption for the random walk model is that the mean advection is negligible. For the central LS this assumption is confirmed by the mean current field derived from the eddy resolving float trajectories (Figure 8). Statistical standard errors of the mean velocity field in the central LS are generally larger than the mean values itself and the velocity field shows no preferred direction. There is neither a generally mean convergent pattern nor a mean flow that would affect the result of a random walk model.

[25] A seasonal cycle of EKE that is a substantial part of the temporal variability in the LS has been calculated for a box between $56^{\circ}$ and $58.5^{\circ} \mathrm{N}$ and $55^{\circ}$ and $50^{\circ} \mathrm{W}$ (Figure 1) independently from satellite altimetry, moored records and float trajectories (Table 4). As already seen in earlier studies [Lilly et al., 2003; Brandt et al., 2004] a distinct peak in the EKE is found during AMJ directly after the convective season. The Rossby radius in the above mentioned box was almost constant in the seasonal cycle. Although the AMJ EKE maximum is hardly statistically significant it has been found independently in float trajectories, moored and altimetric data.

\section{Discussion}

[26] The main result of the present study is a quantification of the eddy diffusivity in the LS from float trajectories, moored observations and altimetry. While the eddy diffusivity from the residence time approach is about $300 \mathrm{~m}^{2} \mathrm{~s}^{-1}$, it is between 950 and $1100 \mathrm{~m}^{2} \mathrm{~s}^{-1}$ using EKE and length scales from different data sets acquired in the central LS.

[27] This discrepancy might be explained by the inhomogeneity of the eddy diffusivity. Both the float-based estimate

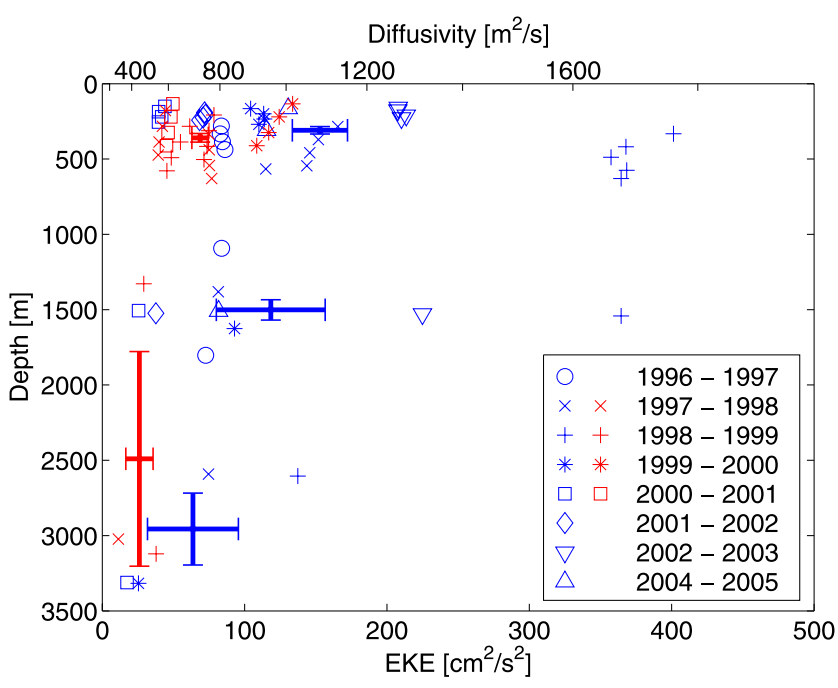

Figure 6. Eddy diffusivity (top axis) and EKE (bottom axis) from about yearly moored velocity records acquired in the central LS at mooring K1 (blue) and acquired farther northwest of K1 (red). Eddy diffusivities are grouped into depth clusters and their respective mean with standard errors are given for K1 (blue) and moorings farther northwest (red). For mooring positions see Figure 2a. 

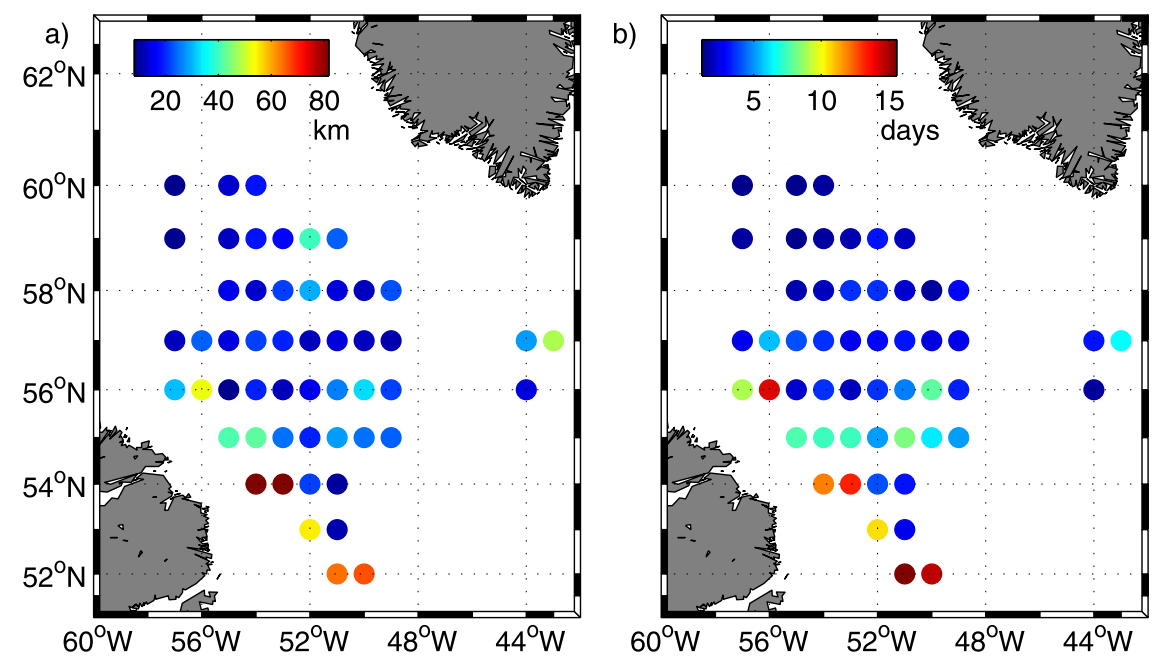

Figure 7. (a) Lagrangian integral length scale and (b) Lagrangian integral timescale calculated from eddy resolving float trajectories. Values were only calculated if the trajectory was known for at least 20 days before and 20 days after the corresponding position.

of $\overline{u^{\prime}}$ of Straneo et al. [2003] and our altimetric EKE distribution show a distinct minimum along the $3000 \mathrm{~m}$ isobath between $56.5^{\circ} \mathrm{N}$ and $59^{\circ} \mathrm{N}$ on the Labrador side of the basin. The moored current meter records confirm this picture. In the region of minimum EKE, the EKE from moored observations yields eddy diffusivities of about $720 \mathrm{~m}^{2} \mathrm{~s}^{-1}$ for depths shallower than $1000 \mathrm{~m}$ and $474 \mathrm{~m}^{2}$ $\mathrm{s}^{-1}, 296 \mathrm{~m}^{2} \mathrm{~s}^{-1}$ and $540 \mathrm{~m}^{2} \mathrm{~s}^{-1}$ for the $1328 \mathrm{~m}, 3023 \mathrm{~m}$, and $3121 \mathrm{~m}$ records.

[28] It is somehow surprising that estimates of eddy diffusivities from $1 / 3$ day eddy resolving float trajectories are so similar to the results of earlier estimates obtained from 5, 10 and 20 day resolution trajectories, e.g., the map of Straneo et al. [2003]. While the mean Lagrangian length scale of $11.5 \mathrm{~km}$ observed from the eddy resolving float trajectories is significantly smaller than the $20 \mathrm{~km}$ used by Straneo et al. [2003], the higher resolution also gives higher values of $\overline{u^{\prime 2}}$, resulting in similar values for $K_{h}$.

[29] Although the spatially variable diffusivity of Straneo et al. [2003] seems to be a very reasonable approach, Kvaleberg et al. [2008] were not able to reproduce the observed CFC distribution [Rhein et al., 2002] in an advective-diffusive model using this diffusivity. On the other hand the overall $\chi^{2}$ used as a measure of the reproduction quality was not sensitive to changes in the constant eddy diffusivity over a range from $500-3000 \mathrm{~m}^{2} \mathrm{~s}^{-1}$, and the $\chi^{2}$ of the variable diffusivity was in the same range. However, their analysis suffered from an unrealistic almost point-like injection of the CFC. Several studies have discussed the possibilities of further formation regions of LSW as, e.g., the southwestern boundary current regime of the LS [Cuny et al., 2005; Brandt et al., 2007] or the Irminger Sea [Pickart et al., 2003; Kieke et al., 2006].

[30] Irrespective of these uncertainties about the injection regions of CFCs, the existence of both the big and homogeneous patch of CFC in the central LS and the sharp concentration gradient near the boundary current suggests that the variable diffusivity with high values in the central LS and low values between boundary current and central LS is necessary to realistically describe the CFC spreading (see Kvaleberg et al. [2008], especially the sharp gradients in Figures $3 \mathrm{a}$ and $3 \mathrm{~d}$ and the homogeneous patch in Figures $3 \mathrm{~b}$, $3 \mathrm{c}$, and $3 \mathrm{~d})$.

[31] These different regimes also lead to different timescales needed for either the homogenization of the central

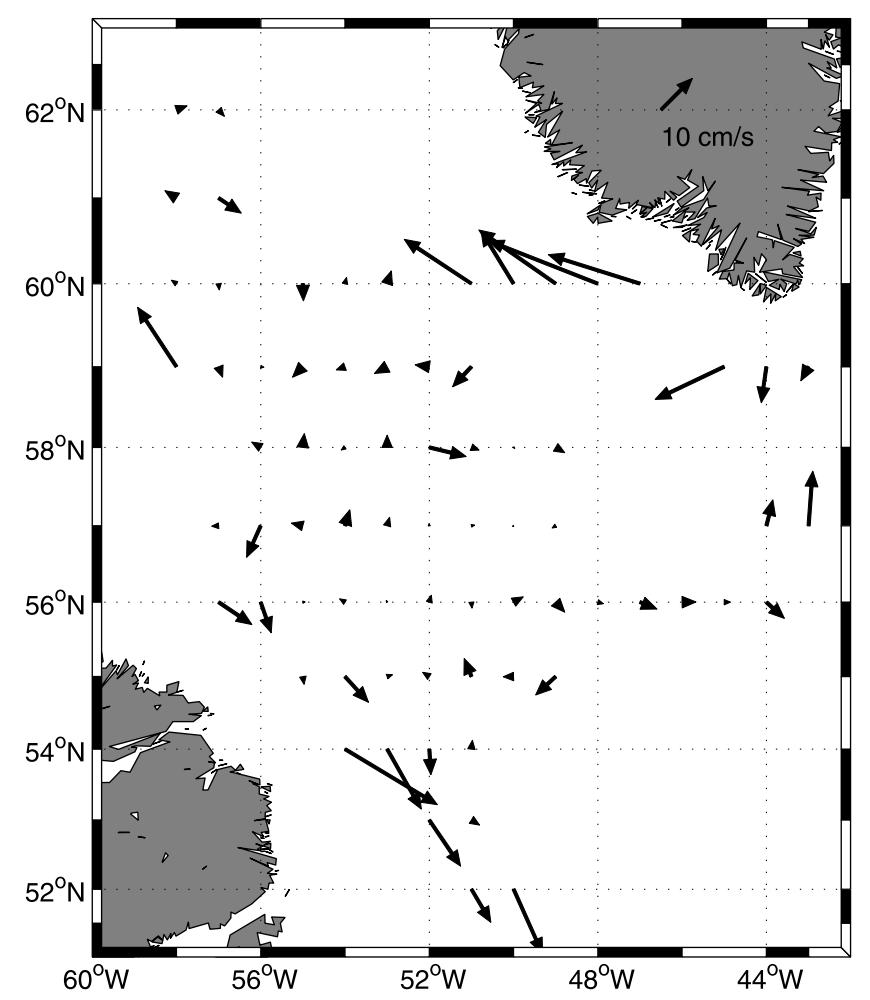

Figure 8. Mean middepth current field derived from eddy resolving float trajectories. Reference arrow denotes a current speed of $10 \mathrm{~cm} \mathrm{~s}^{-1}$. 


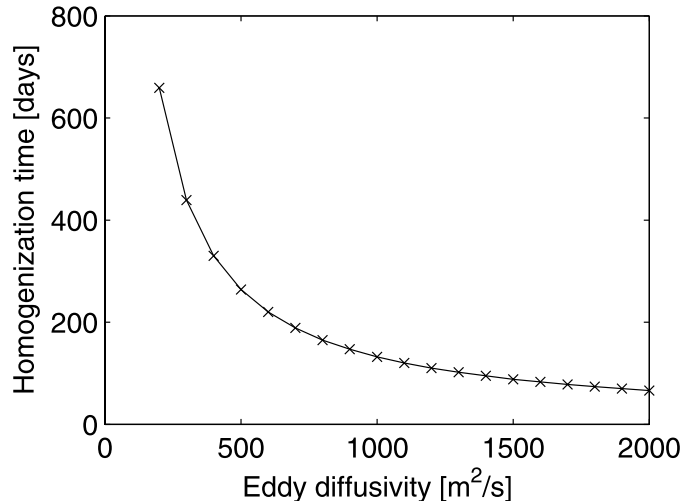

Figure 9. Time needed to homogenize an initially steplike tracer concentration jump between central LS and boundary current as a function of eddy diffusivity. Homogenization is reached when the initial tracer concentration difference is reduced by $1 / e$. See text for details.

LS or the multiyear restratification and export of LSW after a period of intense convection. Here, we applied a horizontal diffusion equation

$$
\frac{\partial C}{\partial t}=K_{h}\left(\frac{\partial^{2}}{\partial x^{2}}+\frac{\partial^{2}}{\partial y^{2}}\right) C
$$

to a step-like tracer distribution separating an inner circle with a radius of $150 \mathrm{~km}$ and an outer circle of $250 \mathrm{~km}$ radius, similarly to the work of Straneo [2006]. Straneo [2006] found from profiling float data that the central LS is homogenized within 2-3 months. Our numerical calculation yields that an eddy diffusivity of about $1800 \mathrm{~m}^{2} \mathrm{~s}^{-1}$ breaks up the tracer concentration gradient and builds up a homogenized layer in 75 days (Figure 9). The criterion for a homogenized layer was a reduction of the maximum tracer concentration difference to $1 / e$ or $37 \%$ of its original value. An eddy diffusivity of $300 \mathrm{~m}^{2} \mathrm{~s}^{-1}$ as found comparing observed and simulated residence time distributions leads to a homogenization time of 440 days. This time is larger than our observed (and underestimated) mean residence time of 248 days, but fits well with the observation that most of our RAFOS floats did not leave the central LS during their 16 months life time.

[32] While the multiyear restratification process is well known from CTD sections in the LS [Stramma et al., 2004; Kieke et al., 2006, 2007; Yashayaev, 2007] the faster process on the shorter timescale is more difficult to assess. Although a fast export of freshly generated LSW on similarly short timescales is taking place in the southwestern boundary current regime, obviously a barrier exists that prohibits a similarly fast exchange between central LS and boundary current.

[33] The relative contribution of these different regimes and processes are discussed in a recent work of Palter et al. [2008]. By analyzing data from profiling floats, they estimated the relative parts of LSW entering the deep western boundary current and found that LSW generated in the central LS entering the boundary current via eddy fluxes and LSW generated in the boundary current contribute with a similar order of magnitude.
[34] The long residence times observed in our float data were also seen by Lavender et al. [2005]. Their definition of the LS box included the cyclonic boundary currents and they yielded mean residence times of 561 days for floats that left the LS and an even longer mean residence time of 641 days for floats that stopped their missions before leaving the LS. For our combined float data set we got mean residence times of 180 days for floats that left the central LS (43 trajectories) and 371 days for floats that stopped their missions before leaving the LS (24 trajectories), however our box was smaller and Lavender et al. [2005] used only floats with a lifetime of more than 200 days. Straneo et al. [2003] applied a similar residence time approach in their advective-diffusive model and got residence times of $4-5$ years in the Labrador basin (which is by far larger than our box).

[35] The most plausible explanation for our different eddy diffusivities as well as the different timescales from different hydrographic measurements and earlier float data is the schematic of an exchange of LSW between central LS and boundary current that is determined by relatively low diffusivities below $500 \mathrm{~m}^{2} \mathrm{~s}^{-1}$, while the processes within and the homogenization of the central LS are described best by higher diffusivities of about $1000 \mathrm{~m}^{2} \mathrm{~s}^{-1}$ (Figure 10). An open question in this picture is the role of the West Greenland Current high-EKE region. While the fastest export pathways might result from floats that take the direct route to the deep Labrador Current, the northeastern boundary of the central LS towards the West Greenland Current with its high EKE and accordingly high eddy diffusivity should be a preferred pathway out of the central LS. Such a pathway around a low-pressure cell in the northwestern LS [Lavender et al., 2000; Faure and Speer, 2005] was also discussed by Straneo et al. [2003]. However, none of our acoustically tracked floats left the LS by following this

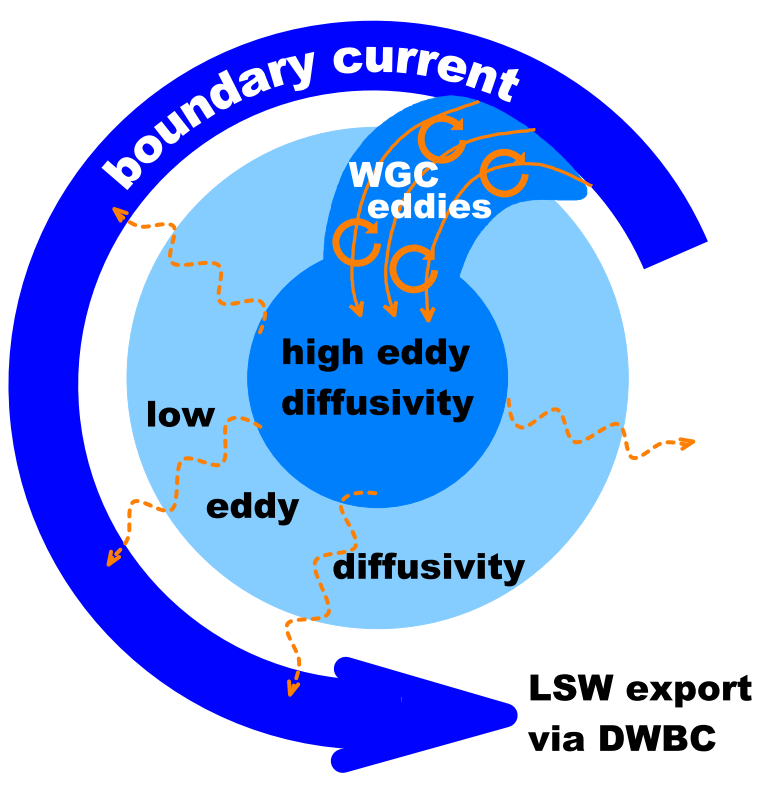

Figure 10. Schematic of exchange between central LS and boundary current. High eddy diffusivities in the central LS result in a fast homogenization, while low eddy diffusivities between central LS and boundary current are responsible for the weak exchange of LSW between both regimes. 
pathway. The eddy diffusivity obtained from the residence time approach is substantially smaller than the high eddy diffusivity in the West Greenland Current high-EKE region north of the central LS. Instead it is similar to the low eddy diffusivity in the region surrounding otherwise the central LS suggesting that the diffusivity in this region sets the weak exchange between central LS and boundary current. However, the irregular distribution of floats with particularly more start positions in the central and southern LS might mask the importance of the northwestern recirculation cell for the exchange between central LS and boundary current system.

[36] Acknowledgments. This work was supported by the German Science Foundation (DFG) as part of the "Sonderforschungsbereich" SFB 460 "Dynamics of Thermohaline Circulation Variability." The altimeter products were produced by SSALTO/DUACS and distributed by AVISO with support from CNES. The Argo data were collected and made freely available by the International Argo Project and the national programs that contribute to it. (http://www.argo.ucsd.edu and http://argo.jcommops.org) Argo is a pilot program of the Global Ocean Observing System. The suggestions and comments of two anonymous reviewers were very helpful to improve and clarify the paper.

\section{References}

Antonov, J. I., R. A. Locarnini, T. P. Boyer, A. V. Mishonov, and H. E. Garcia (2006), World Ocean Atlas 2005, vol. 2, Salinity, NOAA Atlas NESDIS, vol. 62, edited by S. Levitus, 182 pp., NOAA, Silver Spring, Md.

Avsic, T., J. Karstensen, U. Send, and J. Fischer (2006), Interannual variability of newly formed Labrador Sea Water from 1994 to 2005, Geophys. Res. Lett., 33, L21S02, doi:10.1029/2006GL026913.

Böning, C. W. (1988), Characteristics of particle dispersion in the North Atlantic: An alternative interpretation of SOFAR float results, Deep Sea Res., Part A, 35, 1379-1385.

Böning, C. W., and M. D. Cox (1987), Particle dispersion and mixing of conservative properties in an eddy-resolving model, J. Phys. Oceanogr. $18,320-338$.

Brandt, P., F. Schott, A. Funk, and C. Sena Martins (2004), Seasonal to interannual variability of the eddy field in the Labrador Sea from satellite altimetry, J. Geophys. Res., 109, C02028, doi:10.1029/2002JC001551.

Brandt, P., A. Funk, L. Czeschel, C. Eden, and C. W. Böning (2007), Ventilation and transformation of Labrador Sea Water and its rapid export in the deep Labrador Current, J. Phys. Oceanogr., 37, 946-961.

Cuny, J., P. B. Rhines, F. Schott, and J. Lazier (2005), Convection above the Labrador continental slope, J. Phys. Oceanogr., 35, 489-511.

Eden, C. (2007), Eddy length scales in the North Atlantic Ocean, J. Geophys. Res., 112, C06004, doi:10.1029/2006JC003901.

Eden, C., R. J. Greatbatch, and J. Willebrand (2007), A diagnosis of thickness fluxes in an eddy-resolving model, J. Phys. Oceanogr., 37, $727-742$.

Faure, V., and K. Speer (2005), Labrador Sea Water circulation in the Northern North Atlantic Ocean, Deep Sea Res.. Part II, 52, 565-581.

Fischer, J., and F. Schott (2002), Labrador Sea Water tracked by profiling floats - From the boundary current into the open North Atlantic, J. Phys. Oceanogr., 32, 573-584.

Gent, P. R., and J. C. McWilliams (1990), Isopycnal mixing in ocean circulation models, J. Phys. Oceanogr., 20, 150-155.

Khatiwala, S., P. Schlosser, and M. Visbeck (2002), Rates and mechanisms of water mass transformation in the Labrador Sea as inferred from tracer observations, J. Phys. Oceanogr., 32, 666-686.

Kieke, D., M. Rhein, L. Stramma, W. M. Smethie, D. A. LeBel, and W. Zenk (2006), Changes in the CFC inventories and formation rates of upper Labrador Sea Water, 1997-2001, J. Phys. Oceanogr., 36, 64-86.

Kieke, D., M. Rhein, L. Stramma, W. M. Smethie, J. L. Bullister, and D. A. LeBel (2007), Changes in the pool of Labrador Sea Water in the subpolar North Atlantic, Geophys. Res. Lett., 34, L06605, doi:10.1029/ 2006GL028959.

Krauß, W., and C. W. Böning (1987), Lagrangian properties of eddy fields in the northern North Atlantic as deduced from satellite-tracked buoys, J. Mar. Res., 45, 259-291.
Kvaleberg, E., T. W. N. Haine, and D. W. Waugh (2008), Middepth spreading in the subpolar North Atlantic Ocean: Reconciling CFC-11 and float observations, J. Geophys. Res., 113, C08019, doi:10.1029/2007JC004104.

Lavender, K. L., R. E. Davis, and W. B. Owens (2000), Mid-depth recirculation observed in the interior Labrador and Irminger seas by direct velocity measurements, Nature, 407, 66-69.

Lavender, K. L., W. B. Owens, and R. E. Davis (2005), The mid-depth circulation of the subpolar North Atlantic Ocean as measured by subsurface floats, Deep Sea Res., Part I, 52, 767-785.

Lazier, J., R. Hendry, A. Clarke, I. Yashayaev, and P. Rhines (2002), Convection and restratification in the Labrador Sea, 1990-2000, Deep Sea Res., Part I, 49, 1819-1835.

Lilly, J. M., P. B. Rhines, F. Schott, K. Lavender, J. Lazier, and U. Send (2003), Observations of the Labrador Sea eddy field, Prog. Oceanogr., $59,75-176$.

Locarnini, R. A., A. V. Mishonov, J. I. Antonov, T. P. Boyer, and H. E. Garcia (2006), World Ocean Atlas 2005, vol. 1, Temperature, NOAA Atlas NESDIS, vol. 61, edited by S. Levitus, 182 pp., NOAA, Silver Spring, Md.

Lumpkin, R., A.-M. Treguier, and K. Speer (2002), Lagrangian eddy scales in the northern Atlantic Ocean, J. Phys. Oceanogr., 32, 2425-2440.

Machín, F., U. Send, and W. Zenk (2006), Intercomparing drifts from RAFOS and profiling floats in the deep western boundary current along the mid-Atlantic Ridge, Sci. Mar., 70, 1-8.

Marshall, J., and F. Schott (1999), Open-Ocean Convection: Observations, Theory, and Models, Rev. Geophys., 37, 1-64.

Middleton, J. F. (1985), Drifter spectra and diffusivities, J. Mar. Res., 43 , $37-55$.

Palter, J. B., M. S. Lozier, and K. L. Lavender (2008), How does Labrador Sea Water enter the Deep Western Boundary Current?, J. Phys. Oceanogr., 38, 968-983.

Pickart, R. S., F. Straneo, and G. W. K. Moore (2003), Is Labrador Sea Water formed in the Irminger basin?, Deep Sea Res., Part I, 50, 23-52.

Prater, M. D. (2002), Eddies in the Labrador Sea as observed by profiling RAFOS floats and remote sensing, J. Phys. Oceanogr., 32, 411-427.

Rhein, M., J. Fischer, W. M. Smethie, D. Smythe-Wright, R. F. Weiss, C. Mertens, D. H. Min, U. Fleischmann, and A. Putzka (2002), Labrador Sea Water: Pathways, CFC-inventory and formation rates, J. Phys. Oceanogr., 32, 648-665.

Schott, F. A., R. Zantopp, M. Dengler, J. Fischer, and M. Wibaux (2004), Circulation and deep-water export at the western exit of the subpolar North Atlantic, J. Phys. Oceanogr., 34, 817-843.

Stammer, D. (1997), Global characteristics of ocean variability from regional TOPEX/POSEIDON altimeter measurements, J. Phys. Oceanogr., 27, $1743-1769$

Stramma, L., D. Kieke, M. Rhein, F. Schott, I. Yashayaev, and K. P. Koltermann (2004), Deep water changes at the western boundary of the subpolar North Atlantic during 1996 to 2001, Deep Sea Res., Part I, 51, $1033-1056$.

Straneo, F. (2006), Heat and freshwater transport through the central Labrador Sea, J. Phys. Oceanogr., 36, 606-628.

Straneo, F., R. S. Pickart, and K. Lavender (2003), Spreading of Labrador Sea water: An advective-diffusive study based on Lagrangian data, Deep Sea Res., Part I, 50, 701-719.

Talley, L. D., and M. S. McCartney (1982), Distribution and circulation of Labrador Sea Water, J. Phys. Oceanogr., 12, 1189-1205.

Taylor, G. I. (1922), Diffusion by continuous movements, Proc. London Math. Soc., 20(1), 196-212, doi:10.1112/plms/s2-20.1.196.

Wooding, C. M., H. H. Furey, and M. A. Pacheco (2005), RAFOS Float Processing at the Woods Hole Oceanographic Institution, Tech. Rep. WHOI-2005-2, Woods Hole Oceanogr. Inst., Woods Hole, Mass.

Yashayaev, I. (2007), Hydrographic changes in the Labrador Sea, 1960-2005, Progr. Oceanogr., 73, 242-276, doi:10.1016/j.pocean.2007.04.015.

Yashayaev, I., H. M. van Aken, N. P. Holliday, and M. Bersch (2007), Transformation of the Labrador Sea Water in the subpolar North Atlantic, Geophys. Res. Lett., 34, L22605, doi:10.1029/2007GL031812.

Zenk, W., A. Pinck, S. Becker, and P. Tillier (2000), The float park: A new tool for a cost-effective collection of Lagrangian time series with dual release RAFOS floats, J. Atmos. Oceanic Technol., 17, 1439-1443.

P. Brandt, T. Fischer, and A. Funk, Leibniz-Institut für Meereswissenschaften, IFM-GEOMAR, Düsternbrooker Weg 20, D-24105 Kiel, Germany. (afunk@ifm-geomar.de) 